\title{
After Postmaterialism: An Essay on China, Russia and the United States ${ }^{1}$
}

ROBERT BRYM

Abstract. The postmaterialist thesis makes two main claims. First, over time, rising affluence enables many people to substantially satisfy their need for security and economic sustenance, allowing them to focus on pursuing personal autonomy and self-expression. Second, at a given time, younger people, individuals in higher socio-economic positions and wealthier societies tend to be more postmaterialistic than are older people, individuals in lower socio-economic positions and poorer societies. Cursory analysis of American, Chinese and Russian survey data since the late 1980s demonstrates that some of these generalizations are difficult to sustain. While postmaterialism may have been on the rise in some countries in the last decades of the 20th century, it seems now to be a waning force among major world powers, giving way to increasing nationalism and xenophobia. The absence in postmaterialist theory of an adequate explanation for this trend suggests the need to pay more attention to the causes of alternative development paths. Two such causes are outlined in this essay: intensifying geopolitical rivalries and growing economic inequality.

Keywords: Political sociology, Values, Postmaterialism, China, Russia, United States

\section{Big EXCEPTIONS}

T's he Smolny Institute in St. Petersburg was founded about 200 years ago by Catherine the Great to promote the education of young women from the Russian nobility. It represents an early step in the long and unfinished march toward gender equality in Russia. A century later, during the October Revolution, the Smolny embarked on a different path. It be-

1. I am grateful to Reza Nakhaie, Djordje Stefanovic and Jack Veugelers for helpful comments on a draft. Please address correspondence to rbrym@ chass.utoronto.ca. An earlier version of this paper was presented as a keynote address to the political sociology section of the Canadian Sociological Association (Ottawa: 2015). 
came the headquarters of the Bolsheviks and thus an engine of Russia's remarkable economic growth in the twentieth century.

In 2012, Ronald Inglehart, the originator of the theory of postmaterialism and the driving force behind the World Values Survey, wove these two strands of Smolny history together without realizing it. He gave a lecture at the Smolny drawing a strong connection between economic growth, on the one hand, and attitudes toward gender equality and a host of related values, on the other. In his words,

in literally hundreds of surveys in nearly 100 countries in repeated waves, we find a pattern... which...points to the fact that growing existential security leads to changing values.... [T] hese changes lead to growing tolerance of gays, gender equality, more [political] participation, and in the long run, it makes democracy more probable (Inglehart, 2012).

In a nutshell, this is the theory of postmaterialism.

In recent iterations, Inglehart holds that the world's countries can be located in a two-dimensional space, with the $\mathrm{x}$-axis representing survival vs. self-expression values and the y-axis representing traditional versus secular-rational values (Inglehart \& Baker, 2000). In general, he argues, as economic well-being measured by GDP per capita increases, people move to the upper right quadrant of this space, becoming more gender egalitarian, happier, more trusting, less religious, less beholden to authority, less xenophobic, less patriotic and so on.

Forty-seven minutes into the Smolny lecture, after members of the audience had had a chance to inspect Inglehart's graph, a well-mannered gentleman quietly interjected, "I'm sorry, but where is Russia?" It was an excellent question. "Russia," replied Inglehart,

is a special case. Most countries have been moving toward a little more secularization, and quite a lot towards self-expression values. Russia has moved in a retrograde direction, toward more traditional values and a bit more toward survival values. The theory, of course, does not say that every country in the world is magically drawn in this direction. The theory is that if the population grows up under increasing security, then it is drawn in this direction. Russia's recent history, following the collapse of Communism, was not rising security; it was declining security (Inglehart, 2012).

The plausibility of Inglehart's explanation for Russian exceptionalism hangs on what one means by "recent." True, Russia's GDP per capita fell 61 percent between the collapse of communism in 1991 and 1999, giving rise to widespread poverty; but it rose 999 percent from 1999 to 2013 (Google, 2016b). Nonetheless, after nearly a generation of increasing economic security, Russians' values continued to move in a "retrograde direction." 
If Russia is a special case, what about China? China, it turns out, is also a special case. Inglehart boldly noted that because "China has been experiencing a $10 \%$ yearly economic growth rate [actually, more than 11 percent - RB].... It [will] begin to approach Sweden, not immediately, but in the long run" (Inglehart, 2012). In fact, as Inglehart had earlier shown, China's postmaterialist values are mired at the level of Bulgaria's (Inglehart \& Baker, 2000: 40). So despite two generations of the fastest economic growth the world has ever seen, China has not yet registered movement toward the postmaterialist values that Inglehart's theory anticipates.

Such important exceptions suggest the need to examine more closely how all three great powers - Russia, China and the United States have fared in terms of the original postmaterialist scale, first proposed in the late $1980 \mathrm{s.}^{2}$ (In recent work, the scale has become a component of the "survival vs. self-expression" dimension.) The results of this inquiry are displayed in Figure 1.

Figure 1: Postmaterialism, USA, Russia, and China, 1989-2014 (in percent)

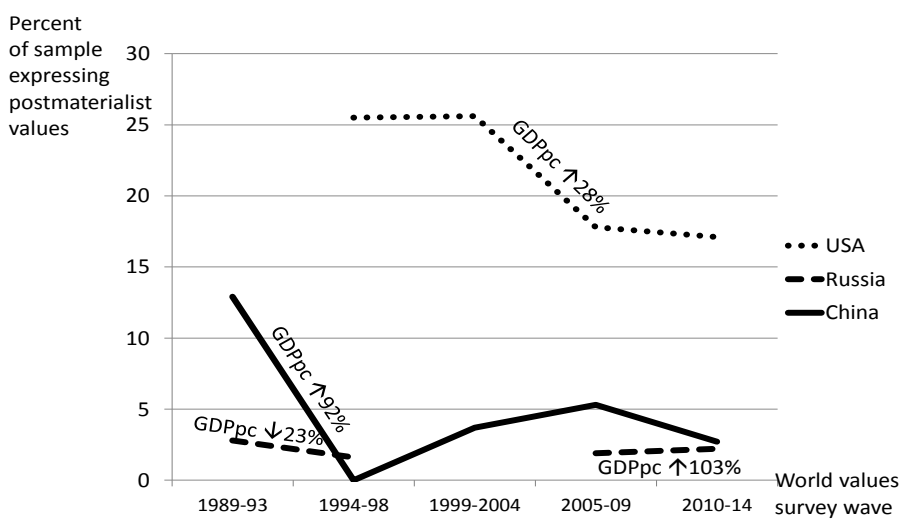

Sources: Google (2016a; 2016b; 2016c); World Values Survey (2014).

In the past quarter of a century, the proportion of Americans expressing postmaterialist values fell more than 8 percentage points to 17 per-

2. The scale is based on responses to the following question: "If you had to choose among the following things, which are the two that seem the most desirable to you?" 1. maintaining order in the nation. 2. giving people more say in important political decisions. 3. fighting rising prices. 4. protecting freedom of speech. Materialists supposedly prioritize items 1 and 3, postmaterialists items 2 and 4 . 
cent while the proportion of Chinese expressing postmaterialist values fell more than 10 percentage points to just 3 percent. The proportion of Russians expressing postmaterialist values dropped insignificantly by less than 1 percentage point in this period. However, only about 2 percent of Russian adults can be called postmaterialists by Inglehart's measure. In fact, among the scores of countries included in the World Values Survey, Russia is the least postmaterialist (Inglehart \& Baker, 2000: 40).

It is true, as Inglehart says, that Russia experienced its sharpest decline in postmaterialist attitudes immediately after the collapse of communism. However, on inspection, the general principle that postmaterialist attitudes are positively correlated with economic growth is not sustained, at least in the short term. Thus, Russia's GPD per capita soared 103 percent in real terms during the oil boom between 2006 and 2012, but the proportion of Russians expressing postmaterialist attitudes barely budged during that period (Figure 1). In China and the United States, the biggest declines in postmaterialism occurred during periods of rapid economic expansion. In the United States, GDP per capita rose 28 percent in real terms between 1999 and 2005 while in China GDP per capita shot up 92 percent in real terms between 1990 and 1995. Yet these periods witnessed the biggest declines in the proportion of Americans and Chinese expressing postmaterialist attitudes over the 25 -year period under analysis. If Figure 1 shows that, for more than a generation, postmaterialist values have been declining in China and the United States and remaining approximately steady at the world's lowest levels in Russia, analysis of short-term trends suggests that five- to seven-year periods of rapid economic growth are often associated with the sharp declines in postmaterialist values.

\section{Survival vs. Self-expression Values in China}

Given that the world's three main geopolitical powers containing more than a quarter of the planet's population are cases that fail to meet expectations, it seems that proponents of postmaterialist theory would be well advised to reorient their attention to factors leading to increasing materialism. The 2006 Chinese General Social Survey permits a first step toward that goal. It includes three questionnaire items that are correlates of Inglehart's survival vs. self-expression scale (Inglehart \& Baker, 2000: 27). The question, "Do you agree that foreign movies, music and books are having a bad influence on Chinese culture?" measures the respondent's level of xenophobia. The question, "Do you agree that, as long as the economy keeps growing, democratization is unnecessary?" measures the respondent's attitude toward democracy. The question, "Do you agree that obeying the government is always the right thing to do?" measures the respondent's attitude toward authority. Negative answers 
to these questions indicate that the respondent ranks high on the selfexpression dimension, positive answers the opposite. ${ }^{3}$

These three items were combined in a scale. A regression model was then developed to account for variation in the degree to which people value self-expression over survival attitudes. Table 1 summarizes the findings for the 10,151 individuals surveyed.

Table 1: Hierarchical Linear Model for Self-Expression Values, China, 2006 (standard errors in parentheses)

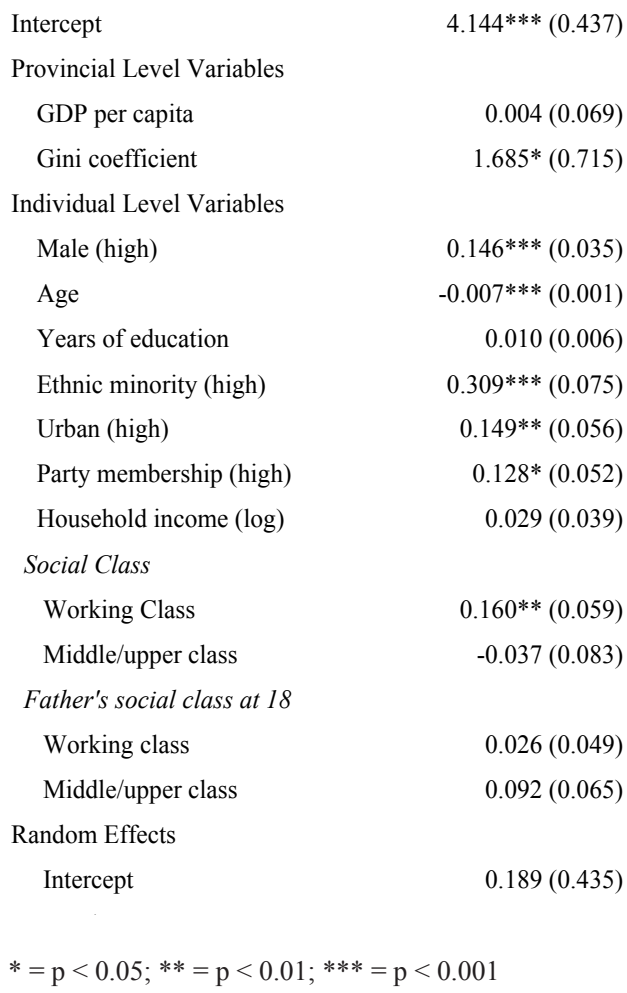

Sources: Zhang, Brym, and Andersen (2015), based on Chinese General Social Survey (2014).

Postmaterialist theory leads one to expect significant associations between the self-expression scale and the twelve predictors in Table 1. Six

3. The questions are not well constructed insofar as they are not neutrally phrased, but here we are interested in their correlates, not their level. 
predictors behaved as expected. Six did not. People who were younger, male and more highly educated valued self-expression more than did people who were older, female and less highly educated. Members of the working class and Party members valued self-expression more than peasants and non-Party members did. These findings suggest that some indicators of higher social status were associated with valuing self-expression, especially for people who experienced primary socialization in more prosperous times, as the postmaterialist thesis predicts. On the other hand, results for half of the predictors do not support the postmaterialist thesis. These surprises are worth pondering.

In the postmaterialist view, placing a high value on self-expression should be associated with occupying a higher current class location and having originated in a higher class. Yet Table 1 shows that Chinese people originating in the working, middle and upper classes were no more likely than were people originating in the peasantry to place a high value on self-expression. Furthermore, people located in the middle and upper classes at the time of the survey were no more likely to favour selfexpression values than were peasants. Similarly with annual income: Although, following the postmaterialist thesis, lower income earners were expected to favour survival values more than higher income earners were, no such association was discovered. It is also consistent with (although not explicitly stated by) the postmaterialist thesis that members of disadvantaged minority groups would be more concerned with survival values than with self-expression values but that is not what was found.

In addition to showing the effects of individual-level variables, Table 1 displays contextual effects at the level of the province, autonomous region and centrally-controlled municipality. Twenty-eight such units are represented in the survey. Postmaterialist theory holds that contextual affluence causes survival values to fade in importance and self-expression values to blossom. The contexts examined in Table 1 exhibit considerable variation in affluence, with the poorest contexts having a median household income only a fifth that of the richest. Yet despite this wide variation, no significant difference in self-expression values was found between the richest and the poorest contexts.

One way of summarizing these results is to say that if one were to select any one of the twelve predictors at random, it would have a 50-50 chance of behaving the way postmaterlialist theory says it should: hardly a glowing endorsement of the theory's validity. 


\section{Antisemitism in Russia}

A few years ago, a team of survey researchers similarly demonstrated that, in Russia, urban, well-educated and well-off respondents are the country's least postmaterialist citizens (Shaykhutdinov et al., 2010). Additional evidence concerning xenophobia increases one's scepticism about the relevance of the postmaterialist thesis to the Russian case.

According to the postmaterialist thesis, tolerance of minorities is a component of postmaterialism and is therefore positively associated with economic well-being. Jews are not the most disliked minority group in Russia. Chechens are. However, between 1999 and 2005, the World Values Survey asked a representative sample of Russian adults how they would feel about having Jews as next-door neighbours. The percentage who said they would not like to have Jews as next-door neighbours was nearly twice as high in Russia as it was in France, Germany, and the UK, and more than five times higher than the comparable figure in the Netherlands and Canada outside Quebec (Brym, Shaffir \& Weinfeld, 2010: vii). Moreover, in the most recent years for which data are available, 40 to 50 percent of Russians agreed with the statement that "Jews in Russia have too much power and influence" (Figure 2). This statement has deep anti-Semitic overtones in Russia, where a pamphlet outlining the alleged Jewish plan for world domination was first published and widely disseminated by the Tsarist secret police in 1905 and continues to be widely distributed (Anonymous, 1923).

Figure 2 : Economic Misery and Anti-Semitism, Russia, 1993-2007

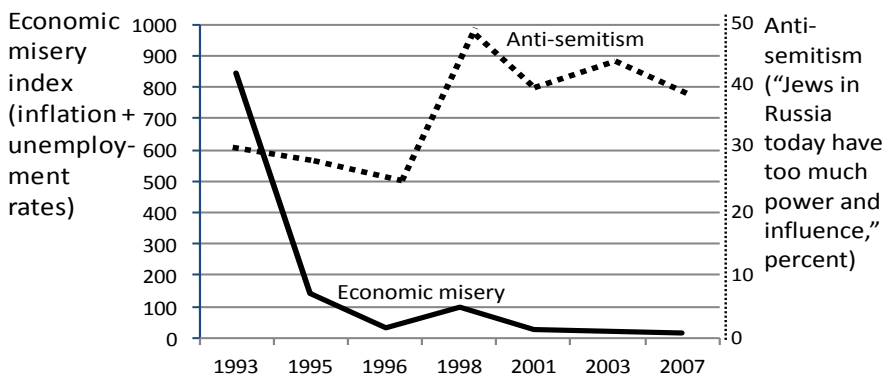

Sources: Stefanovic, Brym, and Evans (2014), based on Eurequal (2012); Inflation.eu (2016); International Labour Organisation (2014); "Russia: Inflation" (1996); World Bank (2014). 
As Figure 2 shows, between 1993 and 2007 the proportion of Russians agreeing that Jews have too much power and influence rose markedly. Yet over this period, the size of the Jewish population fell by 45 percent to about 210,000 and the population aged to the point at which nearly half the Jews in Russia were pensioners (2002 median age $=57.5)$ - hardly indicative of growing power and influence (American Jewish Yearbook, 1995: 478; 2007: 583; Federal Service of State Statistics, 2004). More importantly from the point of view of the postmaterialist thesis, the proportion of Russians agreeing that Jews have too much power and influence jumped as the economic situation of the country vastly improved (Brym, 2002). ${ }^{4}$ Thus, although the xenophobic element of postmaterialism may fall with improving economic conditions in some contexts, the Russian case demonstrates that the opposite may also happen. Other indicators of the tolerance that is supposed to accompany economic growth and increasing security, notably attitudes towards sexual minorities, have moved in the same direction as anti-Semitism: toward greater intolerance.

\section{CAuses of Insecurity}

The foregoing considerations suggest that the postmaterialist thesis does not adequately explain trends in value change in the leading geopolitical powers over the past few decades. Its inadequacy is not due only to its presumption of a universal, historical trend toward higher levels of postmaterialism - a view that Inglehart conveniently summarized in his claim that Chinese values will eventually approach those of Sweden (Inglehart, 2012). More profoundly, the postmaterialist thesis pays insufficient attention to the causes of insecurity that may (only temporarily in Inglehart's judgment) give rise to a countertendency toward materialism.

By insecurity, Inglehart usually means declining material well-being as measured by falling GDP per capita. Thus, he acknowledges that progress toward postmaterialism may be interrupted by economic setbacks, as illustrated by Russia in the decade after the collapse of communism. However, he ignores more important causes of insecurity - more im-

4. The collapse of the Russian rouble in 1998 prompted a hard-line general and Communist member of the Duma to assert in a television interview that all of Russia's economic woes are the fault of the Jews, who should be expelled from Russia. In an open letter, the head of the still-popular Communist Party of the Russian Federation later qualified that assessment, stating that the problem was caused by "the Zionization of the governmental authorities of Russia." During the ensuing public debate, polls registered a spike in antiJewish sentiment that abated only modestly over the next nine years despite greatly improved economic conditions. 
portant in the sense that they can overwhelm the effects of GDP per capita and cause a decline in postmaterialist values even when GDP per capita is on the rise. Two such causes of insecurity are world-historical shifts in global power and massive increases in economic inequality, both of which we are witnessing today and to which we now turn.

\section{The Reorientation of the International System}

Today, a politics of intensifying nationalism and xenophobia is being promoted by many people holding powerful positions in the most geopolitically important states. In the context of the well-documented shift in global power away from the United States toward China and, to a lesser degree, Russia (Dobbs et al., 2012: 17; Edelman, 2010; Frank, 1998; Mahbubani, 2008), some members of ruling circles have expressed nationalistic and xenophobic values that have been endorsed by large segments of the public in the countries under examination here. To varying degrees, therefore, self-expression and quality-of-life issues have declined in importance while xenophobia and economic and security concerns have strengthened.

Consider the United States. According to a nationally representative poll taken in 2013, 53 percent of Americans think the United States is less powerful on the world stage than it was a decade earlier, three times more than the percentage who think the United States is more powerful. That is the by far the highest percentage of Americans sensing a decline in their country's power since pollsters started asking this question in 1974. The percentage has more than doubled since 2004. Polls of American foreign relations experts reveal the same tendency over time (Pew, 2013).

Chinese economic and military growth and Islamic radicalism are widely perceived as the two main threats to American dominance, with Russian territorial ambitions more recently coming to the fore. One result of increasing threat perception is rising xenophobia. For example, since $9 / 11$, the proportion of Americans holding an unfavourable opinion of Islam has risen nearly 20 percentage points and stood at nearly 50 percent in 2014 (American Arab Institute, 2014; Kurzman, 2014). The rapid rise of Donald Trump as a galvanizing political force in the United States is the most recent manifestation of a tendency that even conservative analysts have likened to the ascent of Mussolini in the late 1910s and early 1920s (Milbank, 2015).

The United States has responded to its growing sense of threat and declining power by seeking to shore up its security, largely by political and military means. It has launched long and costly wars in the greater Middle East. It has raised its military, diplomatic and economic posture in the Asia/Pacific region and encouraged its allies to do likewise. For example, it has strengthened trade agreements with South Korea and 
other regional powers, sided with the Philippines, Vietnam and Japan in their territorial disputes with China, and increased military cooperation with Australia. Finally, the United States and its Western European allies have invited ten Eastern European countries to join the European Union and twelve Eastern European countries to join the NATO defence alliance as a buffer against Russia. Overall, the American response to its declining position has been aggressively security-oriented.

From the Russian point of view, the United States has wrested away piece after piece of the former Soviet Union's former sphere of influence. Russia views NATO and EU expansion in Eastern Europe as a grave security and economic threat. Ukraine's turn to the West and Russia's subsequent annexation of Crimea and initiation of a proxy war in the Donbas in 2014 are only the most recent reactions to what Russia perceives as Western aggression. In 1992, Transnistria, the eastern slice of Moldova, refused to be separated from the Soviet Union, and a fourmonth armed conflict resulted in Russia stationing its troops there. Today, Russia effectively controls the region. War with Georgia in 2008 resulted in Russia recognizing the provinces of Abkhazia and South Ossetia as independent states, annexing them de facto. Like the United States, Russia has become increasingly security-oriented and aggressive since 2000 .

In 2000, Russia's direction was barely discernible (Brym \& Kosova, 2000). A decade later, the ideology of Eurasianism had taken hold in Russia's highest political circles. In this view, Russia should be the centre of an economic and political union that reintegrates most of the former Soviet Union. In its most extreme version, the Eurasian Empire is seen as extending well beyond the eastern, western and southern borders of the USSR (Barbashin \& Thoburn, 2014; Dugin, 2000; Lukin, 2014; Pomarantsev, 2013; Putin, 2014; Shlapentokh, 2014).

The Russian public has fallen in with this stance. Surveys show that Russians have become more traditional, religious, xenophobic and imperialistic in recent decades. They have been flocking to the highly conservative and ethnically and religiously intolerant Russian Orthodox Church, which the state now strongly supports and heavily subsidizes (Evans \& Northmore-Ball, 2012). In 1991, 37 percent minority of Russians thought it was natural for their country to be an empire. In 2012, a 44 percent plurality agreed. In 1991, 26 percent of Russians said that their country should exclude non-Russian minorities. By 2012, that figure had more than doubled to 53 percent (Pew, 2012).

Turning to China, one finds that increasingly nationalistic and xenophobic views were expressed by some intellectuals in the early 1990 s (Zhao, 1997). These attitudes have since strengthened and became entrenched under the leadership of President Xi. Inspired by the glories of China's imperial past, the government has in recent years vastly expanded international trade, investment and influence, especially in Asia, Africa and Latin America; rapidly increased the size and reach of the mil- 
itary; and advanced new Asian and Eurasian security initiatives. China has also become increasingly assertive about its territorial claims in the potentially oil- and gas-rich South China and East China Seas, where it has come into conflict with Vietnam over the Paracel Islands and with Japan over the Senkaku Islands. In this connection, China declared an air defence zone that overlaps Japan's and South Korea's, announced regional fishing regulations that none of its neighbours recognize, and started increasing the size of certain islands to increase the scope of its maritime claims. It even redrew the embossed map on Chinese passports to include disputed areas in India and Southeast Asia. All of these actions have expressed and fuelled nationalistic and xenophobic sentiments in the population (Economy, 2014; Nathan, 2003; Poling, 2013).

\section{RISING INEQUALITY}

Rapidly increasing income inequality seems to have rendered much of the Chinese, American and Russian populations susceptible to nationalistic and xenophobic appeals. In the early 1980s, Russia and China were among the most egalitarian countries in the world as measured by market income (Gini $=0.280)$. Since then, income inequality has increased rapidly in both countries. By 2012, the Chinese Gini very nearly reached the American level (Gini $=.475)$, which had itself been climbing rapidly as competition from low-wage countries caused millions of well-paying manufacturing jobs to disappear (Adomanis, 2012; Oak, 2012; World Bank, 2015).

Research shows that a high level of inequality tends to make people dissatisfied with life, although their dissatisfaction is expressed to varying degrees, in different forms, and with different consequences across population categories and countries (OECD, 2013: 35). One well-known pattern involves scapegoating or blaming dissatisfaction caused by high and rising inequality on immigrants who compete for jobs and foreign countries that threaten domestic security and economic welfare. Unfortunately, even the American General Social Survey does not allow one to plot economic dissatisfaction and xenophobia against the Gini index because questions about attitudes toward immigrants, China and so on are asked too infrequently. Nonetheless, it seems plausible that three decades of steeply rising income inequality in all three of the countries under examination have helped to weaken postmaterialist values and strengthen nationalism and xenophobia in their populations.

\section{Conclusion}

The foregoing analysis suggests that, in the decades since the postmaterialist thesis was first proposed, value change among the citizens of the 
major world powers has not moved in the direction of greater respect for minorities, stronger endorsement of democracy and so on. To the contrary, the evidence assembled here indicates movement in the opposite direction, and this despite considerable growth in overall prosperity in China, Russia and the United States.

Three corollaries follow. First, as Robert Andersen's (2012) crossnational analysis of popular support for democracy implies, the degree to which a country's citizens support postmaterialist values may be influenced at least as much by the country's level of economic inequality as by its overall level of prosperity — and sometimes more. Rising GDP per capita may bring about an increased sense of security, tolerance and the like, as the postmaterialist thesis insists. However, if rising income and wealth are progressively more concentrated in the hands of the wellto-do, the opposite may result. In the latter case, ordinary citizens may consider themselves increasingly disadvantaged. They may focus more and more on seeking to improve their material well-being and blaming their troubles on domestic or foreign scapegoats. For geopolitical and domestic political reasons, elite groups may be eager to encourage such a value shift away from postmaterialism. The postmaterialist thesis has little or nothing to say about the effects of rising inequality and changing geopolitics on people's sense of insecurity. In contrast, the present essay offers a tentative foray into this line of thought. Hopefully, future research will specify more precisely how variation in economic inequality and geopolitical change modify the relationship between prosperity and postmaterialist values.

A second implication of this essay's argument is that the historical traditions, cultural practices and institutional continuities of countries influence their development paths, so much so that, in some cases, growing prosperity does not necessarily lead to increased individualism, greater democracy and so on. In recent years, proponents of the postmaterialist thesis have acknowledged the significance of path dependency, but only insofar as certain religious or political traditions may weaken the positive association between prosperity and postmaterialism. They do not entertain the possibility that, for some categories of countries, there exists no correlation between prosperity and postmaterialism or that, for other categories of countries, the correlation may be negative. In the words of Welzel, Inglehart and Klingemann (2001: iii), "socioeconomic development, cultural modernization, and democratic regime performance constitute a coherent syndrome of social change (emphasis added)." The evidence presented here questions whether the syndrome is always as coherent as these researchers hold and suggests that it is possible for countries to follow different development paths. Future cross-national analyses of many more countries than the three singled out here should seek to acknowledge, categorize and explain these development paths and their associated value outcomes. 
The third and final analytical upshot of the foregoing analysis is that it is sometimes counterproductive to assume that countries (and their populations) are independent observations. Of course, much can be learned about the sources of value change from cross-national, statistical research based on the assumption of independent observations. However, suspending that assumption and recognizing that, to varying degrees, countries depend on one another economically, politically and culturally can also lead to useful insights. As described earlier, the actions of the United States have strongly influenced the reactions of Russia and the actions of China have strongly influenced the reactions of the United States, with important implications for the values held by the populations of all three countries. Cross-national research on value change has largely ignored such interdependence, leading to conclusions that paint an overly rosy and more or less linear picture of modernization. In contrast, recognizing the existence of an international system adds an important dimension to the study of value change. The picture that emerges from the addition of this dimension is still hazy, but it appears to be more heterogeneous and realistic, and less linear and sanguine, than the postmaterialist thesis allows.

\section{REFERENCES}

Adomanis, Mark. 2012. "Russia's Transition from Communism in Figures: Population, Disposable Income, Pensions, Investment, and Inequality.” Forbes 2 August. http://www.forbes.com/sites/markadomanis/2012/02/08/russias-transition-from-communism-in-figures-population-disposable-income-pensions-investment-and-inequality/ (retrieved 29 February 2016).

American Arab Institute. 2014. "American Attitudes toward Arabs and Muslims." Washington DC. http://b.3cdn.net/aai/3e05a493869e6b44b0 76m 6iyjon.pdf (retrieved 29 February 2016).

American Jewish Yearbook. 1995. "World Jewish Population, 1993.” New York: American Jewish Committee and Jewish Publication Society of America: 466-92.

American Jewish Yearbook. 2007. "World Jewish Population, 2007.” New York: American Jewish Committee and Jewish Publication Society of America: 551-600.

Andersen, Robert. 2012. "Support for Democracy in Cross-national Perspective: The Detrimental Effect of Economic Inequality." Research in Social Stratification and Mobility, 30, 4: 389-402.

Anonymous. 1923 [1905]. Protocols of the Meetings of the Learned Elders of Zion, Victor E. Marsden, trans. London: The Britons. http://ddickerson. igc.org/The Protocols of the Learned Elders_of_Zion.pdf (retrieved 29 February 2016). 
Barbashin, Anton \& Hannah Thoburn. 2014. "Putin's Brain: Alexander Dugin and the Philosophy behind Putin's Invasion of Crimea." Foreign Affairs 31 March. http://www.foreignaffairs.com/articles/141080/anton-barbashin-and-hannah-thoburn/putins-brain (retrieved 29 February 2016).

BBC. 2014. "How uninhabited islands soured China-Japan ties." 9 November. http://www.bbc.com/news/world-asia-pacific-11341139 (retrieved 29 February 2016).

Brym, Robert \& Larissa Kosova. 2000. “Феномен В Путина: морфология и семантика массавой популарности.” [Russian: "The V Putin Phenomenon: Morphology and Semantics of Mass Popularity."] Экономические и сочиальные перемень: мониторинг общественного мнения [Есоnomic and Social Change: Monitoring Public Opinion], 3: 18-22.

Brym, Robert. 2002. "Russian Antisemitism, 1996-2000." Pp. 99-113 in Zvi Gitelman and Marshall Goldman, eds. Jewish Life after the USSR: A Community in Transition. Bloomington IN: Indiana University Press.

Brym, Robert, William Shaffir \& Morton Weinfeld. 2010. "Introduction to the Wynford Edition". In Robert Brym, William Shaffir and Morton Weinfeld, eds., The Jews in Canada. Toronto: Oxford University Press Canada: v-x.

Chinese General Social Survey. 2014. http://www.chinagss.org/ (retrieved 29 February 2016).

Dobbs, Richard, Jaana Remes, James Manyika, Charles Roxburgh, Sven Smit \& Fabian Schaer. 2012. "Urban World: Cities and the Rise of the Consuming Class." McKinsey Global Institute. http://www.mckinsey.com/ insights/urbanization/urban world cities and the rise of the consuming class (retrieved 29 February 2016).

Dugin, Aleksandr. 2000. Основы геополитики: геополитическое будущее России/мыслить пространством, изд. 4 [Russian: Foundations of Geopolitics: The Geopolitical Future of Russia/Thinking Spatially, $4^{\text {th }}$ ed.] Moscow: Arctogaia-tsentr.

Economist, The. 2012. "Troubled waters." 6 August. http://www.economist. com/blogs/analects/2012/08/south-china-sea (retrieved 29 February 2016).

Economy, Elizabeth C. 2014. "China's Imperial President: Xi Jinping Tightens his Grip.” Foreign Affairs 93, 6: 80-92.

Edelman, Eric S. 2010. “Understanding America's Contested Primacy.” Washington DC: Center for Strategic and Budgetary Assessments. http:// www.csbaonline.org/publications/2010/10/understanding-americas-contested-primacy/(retrieved 29 February 2016).

Eurequal. 2012. "About Eurequal”. http://eurequal.politics.ox.ac.uk/about/ (retrieved 29 February 2016). 
Evans, Geoffrey \& Ksenia Northmore-Ball. 2012. "The Limits of Secularization? The Resurgence of Orthodoxy in Post-Soviet Russia." Journal for the Scientific Study of Religion 51 (4): 795-808.

Federal State Statistics Service. 2004. “Население отдельных национальностей по возрастным группам, полу и состоянию в браке.” [Russian: “Population of Individual Nationalities by Age Group, Sex, and Marital Status."] Всероссийская перепись населения 2002 года. [All-Russian Census of the Population 2002.] http://www.perepis2002.ru/index. html?id=17 (retrieved 29 February 2016).

Frank, Andre Gunder. 1998. ReOrient: Global Economy in the Asian Age. Berkeley: University of California Press.

Google. 2016a. "China GDP per capita." https://www.google.ca/?gws

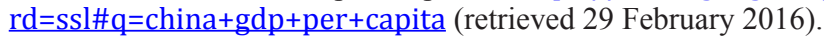

Google. 2016b. "Russia GDP per capita." https://www.google.ca/?gws $\underline{\mathrm{rd}=s s l \# q=R u s s i a+g d p+p e r+c a p i t a}$ (retrieved 29 February 2016).

Google. 2016c. "USA GDP per capita." https://www.google.ca/?gws $\underline{\mathrm{rd}=s \mathrm{sl} \# \mathrm{q}=U S A+g d p+p e r+c a p i t a}$ (retrieved 29 February 2016).

Inflation.eu. 2016. "Historic inflation Russia - CPI inflation." http://www. inflation.eu/inflation-rates/russia/historic-inflation/cpi-inflationrussia.aspx (retrieved 29 February 2016).

Inglehart, Ronald. 2012. “Модернизация - ценности - счастье.” (Russian: "Modernization - Values - Happiness.") St. Petersburg: Smol'niy Institut. http://contextfound.org/events/y2012/m12/n79/ (retrieved 29 February 2016).

Inglehart, Ronald \& Wayne E. Baker. 2000. "Modernization, Cultural Change, and the Persistence of Traditional Values." American Sociological Review 65, 1: 19-51.

International Labour Organisation. 2014. Key Indicators of the Labour Market, 8th ed. http://www.ilo.org/empelm/pubs/WCMS 114060/lang-en/index (retrieved 29 February 2016).

Kurzman, Charles. 2014. "Anti-Muslim Sentiment Rising in the U.S.: What is Happening to Religious Tolerance?" ISLAMiCommentary 13 February. http://islamicommentary.org/2014/02/anti-muslim-sentiment-rising-in-the-u-s-what-is-happening-to-religious-tolerance/ (retrieved 29 February 2016).

Lane, David. 2013. "Dynamics of Regional Inequality in the Russian Federation: Circular and Cumulative Causality." Valdai Discussion Club 2 December. http://valdaiclub.com/economy/65060.html (retrieved 29 February 2016).

Lukin, Alexander. 2014. "What the Kremlin is Thinking: Putin's Vision for Eurasia." Foreign Affairs 93, 4: 85-94. 
Mahbubani, Kishore. 2008. The New Asian Hemisphere: The Irresistible Shift of Global Power to the East. New York: Public Affairs Books.

Milbank, Dana. 2015. "Donald Trump, America's modern Mussolini." Washington Post 8 December. https://www.washingtonpost.com/opinions/donald-trump-isnt-todays-wendell-willkie-hes-todays-benitomussolini/2015/12/08/77c81b0c-9ddc-11e5-a3c5-c77f2cc5a43c story.html (retrieved 29 February 2016).

Nathan, Andrew I. 2003. “Authoritarian Resilience.” Journal of Democracy 14, 1: 6-17.

Oak, Robert. 2012. "The Rich and the Rest of us in the United States." The Economic Populist 12 September. http://www.economicpopulist.org/ content/rich-and-rest-us-united-states (retrieved 29 February 2016).

OECD. 2014. “How's Life? 2013: Measuring Well-Being.” http://www.keepeek.com/Digital-Asset-Management/oecd/economics/how-s-life2013 9789264201392-en\#page1 (retrieved 29 February 2016).

Pew Research Center for the People and the Press. 2012. "Russians Back Protests, Political Freedoms and Putin, Too.” http://www.pewglobal.org/ files/2012/05/Pew-Global-Attitudes-Project-Russia-Report-FINALMAY-23-2012.pdf (retrieved 29 February 2016).

Pew Research Center for the People and the Press. 2013. "Public Sees US Power Declining as Support for Global Engagement Slips." http://www. people-press.org/2013/12/03/public-sees-u-s-power-declining-assupport-for-global-engagement-slips/ (retrieved 29 February 2016).

Poling, Gregory B. 2013. The South China Sea in Focus: Clarifying the Limits of Maritime Dispute. Lanham MD: Rowman \& Littlefield. http://csis.org/ files/publication/130717_Poling_SouthChinaSea_Web.pdf (retrieved 29 February 2016).

Pomarantsev, Peter. 2013. "Russia: A Postmodern Dictatorship?" London: Legatum Institute, Institute of Modern Russia. http://www.li.com/docs/ default-source/publications/pomeransev1 russia imr web final. pdf?sfvrsn $=4$ (retrieved 29 February 2016).

Putin, Vladimir. 2014. "Presidential Address to the Federal Assembly." http:// eng.kremlin.ru/news/23341 (retrieved 29 February 2016).

"Russia: Inflation." 1996. Encyclopedia of the Nations. http://www.countrydata.com/cgi-bin/query/r-11445.html (retrieved 29 February 2016).

Shaykhutdinov, Renat, Andrew Konitzer, Alexadner Pacek \& Vladimir Zvonovskii. 2010. "Education, the Economy, and Post-materialist Values in Russia: Evidence from the Chechnya Conflict." European Journal of Economic and Political Studies 3, 1: 101-20.

Shlapentokh, Dmitry V. 2014. "Implementation of an Ideological Paradigm: Early Duginian Eurasianism and Russia's Post-Crimean Discourse." Contemporary Security Policy 35, 3: 380-99. 
Stefanovic, Djordje, Robert Brym \& Geoffrey Evans. 2014. "Antisemitism in Russia Revisited." Presented at the annual meetings of the Association for the Study of Nationalities. New York: Columbia University.

Welzel, Christian, Ronald Inglehart \& Hans-Dieter Klingemann. 2001. Human Development as a General Theory of Social Change: A Multi-Level and Cross-Cultural Perspective. Berlin: Wissenschaftszentrum Berlin für Sozialforschung. http://worlddatabaseofhappiness.eur.nl/hap bib/freetexts/welzel c 2001A.pdf (retrieved 29 February 2016).

World Bank. 2014. "Indicators". http://data.worldbank.org/indicator (retrieved 29 February 2016).

World Bank. 2015. "Inequality in Focus, August 2013: Experiences from China and Brazil." Poverty 2, 2. http://www.worldbank.org/en/topic/ poverty/publication/inequality-in-focus-august-2013 (retrieved 29 February 2016).

World Values Survey. 2014. "WVS_Longitudinal_1981-2014 spss_v_2014_06_17_Beta." Machine readable file. http://www.worldvaluessurvey.org/WVSDocumentationWVL.jsp (retrieved 29 February 2016).

Zhang, Tony Huiquan, Robert Brym \& Robert Andersen. 2015. "Postmaterialism and Liberalism in China: The Role of Social Class and Inequality." Unpublished paper. Department of Sociology: University of Toronto.

Zhao, Suisheng. 1997. “Chinese Intellectuals' Quest for National Greatness and Nationalistic Writing in the 1990s." The China Quarterly 152: 725-45

Robert Brym, FRSC, is SD Clark Professor of Sociology at the University of Toronto. He has published widely on politics and social movements in Canada, Russia and the Middle East.

Email: $\underline{\text { rbrym@chass.utoronto.ca }}$

Web: https://utoronto.academia.edu/RobertBrym 
212 C C Canadian Journal of Sociology/Cahiers Canadiens de Sociologie 41(2) 2016 